Turkish Journal of Unmanned Aerial Vehicles

Türkiye İnsansız Hava Araçları Dergisi

https://dergipark.org.tr/tr/pub/tiha

e-ISSN 2687-6094

\title{
Türkiye'nin İnsansız Hava Aracı (İHA) İhracat Rekabet Gücünün Analizi
}

\author{
Erdem ATEŞ*1 \\ ${ }^{1}$ Dokuz Eylül Üniversitesi, Íktisadi ve İdari Bilimler Fakültesi, İktisat Bölümü, İzmir, Türkiye
}

\author{
Anahtar Kelimeler \\ İHA \\ Diș ticaret \\ Uluslararası ticaret \\ İhracat rekabet gücü
}

\begin{abstract}
ÖZ
İnsansız Hava Aracı (İHA) pilotu bulunmayan, uzaktan idare edilebilen ve uçabilen sistemler olarak tanımlanabilir. İHA'ların kullanımı günümüzde fazlasıyla yaygınlaşmış durumdadır. İHA başlangıçta askeri amaçlarla ortaya çıkmasına rağmen, özellikle son yıllarda birçok farklı alanda kullanılmaya bașlanmıştır. Türkiye İHA teknolojisinin önemini kavramış ve bu alanda üretici olan ülkelerden biridir. Türkiye'nin ürettiği İHA'ların ağırlıklı olarak askeri amaçlara hizmet etmeyi hedefledikleri görülmektedir. Türkiye ürettiği İHA ve SİHA'ları (Silahlı İnsansız Hava Aracı) bazı ülkelere ihraç etmektedir. İHA piyasasının hızla arttığı ve birçok ülkenin İHA'lara ilgi duyduğu düșünüldüğünde, bunun Türkiye'nin ihracatına ve ekonomik büyümesine katkı sağlayacağı düşünülmektedir. Çalışmanın amacl; Türkiye'nin İHA/SİHA ihracatının rekabet gücünü analiz etmektir. Analizde, 2002-2020 yılları arasında, küresel sınıflandırma sistemlerinden olan HS altı digit verileri kullanılmıștır. Analizde; Avrupa Komisyonu tarafından İHA sınıflandırılmasında yer alan altı ürün grubunun dört tanesi kullanılmıștır. Analize iki ürün grubunun dâhil edilmemesinin nedeni, bu ürün grupları içerisinde İHA ticaretinin payının çok düşük olacağının düşünülmesidir. Çalışmanın amacı; Türkiye'nin İHA ihracatının uluslararası rekabet gücünün belirlenmesidir. Çalışmada, bahsi geçen ürün grupları için Açıklanmıș Karşılaştırmalı Üstünlük Endeksleri (Balassa Endeksleri) Açıklanmış Rekabet Üstünlügü Endeksleri (Vollrath Endeksleri) ve İhracatta Uzmanlaşma Endeksi (ES) hesaplanmıştır. Sonuç olarak; özellikle son yıllarda Türkiye'nin İHA alanında ihracat yoğunlaşmasının arttığı görülmüştür.
\end{abstract}

\section{Analysis of Turkey's Unmanned Aerial Vehicle (UAV) Export Competitiveness}

\author{
Keywords \\ UAV \\ Foreign Trade \\ International Trade \\ Export competitiveness
}

\begin{abstract}
Unmanned Aerial Vehicle (UAV) can be defined as systems that do not have a pilot, can be managed remotely, and can fly. The use of UAVs is very widespread today. Although the UAV initially appeared for military purposes, it has started to be used in many different areas, especially in recent years. Turkey understands the importance of UAV technology and is one of the countries that is a manufacturer in this field. It is seen that the UAVs produced by Turkey are mainly aimed at serving military purposes. Turkey exports its UAVs and Siha (armed unmanned aerial vehicles) to some countries. Considering that the UAV market is growing rapidly, and many countries are interested in UAVs, it is thought that this will contribute to Turkey's exports and economic growth. The aim of the study is to analyze the competitiveness of Turkey's UAV/SIHA exports. The analysis used HS six-digit data from global classification systems between 2002-2020. In the analysis, four of the six product groups included in the classification of UAVs by the European Commission were used. The reason two product groups are not included in the analysis is because it is thought that the share of UAV trade within these product groups will be very low. The aim of the study is to determine the international competitiveness of Turkey's UAV exports. In the study, comparative advantage indices (Balassa Indices) explained competitive advantage indices (Vollrath indices) and export specialization Index (ES) were calculated for the mentioned product groups. As a result, Turkey's export concentration in the field of UAVs has increased, especially in recent years.
\end{abstract}




\section{GİRiş}

İnsansız Hava Aracı (IHA) pilotu bulunmayan, uzaktan kontrol edilebilen veya belirlenen bir rotada kendiliğinden uçabilen araçlara verilen isimdir (Kurt \& Ün, 2015).

IHA'lar başlangıçta askeri amaçlara hizmet etmek amacıyla tasarlanmışlardır. Fakat özellikle son yıllarda sivil amaçlarla da yaygın olarak kullanılmaya başlanmışlardır. IHHA'lar, askeri amaçlarla; keşif, gözetleme, takip, sınır ve kıyı güvenliğinin sağlanması ve saldırı amacıyla kullanılmaktadırlar. Silahlı İnsansız Hava Araçları (Unmanned Combat Aerial Vehicle) (SİHAUCAV) belirlenen hedeflere saldırı düzenlemek için mühimmat taşıyabilen, belli bir komuta merkezinden idare edilen veya önceden belirlenen hedefleri otonom olarak imha edebilen İHA'lardır. Dünyada SïHA kullanan ülke sayısı hızla artmaktadır. 2010 yılında SİHA sahibi ülke sayısı 60 iken, 2019 itibariyle bu sayı 95’e yükselmiştir (Gettinger, 2020)

Sivil amaçlarla ise; tarımda uzaktan algılama uygulamaları, bitki ve ormanlardaki zararlı hașerelerin ve hastalıkların tespiti, kargo taşımacılı̆̆ı, tarihi yapıların görselinin alınması ve 3D modelinin yapılması, hobi amaçlı fotoğraf çekimi, hava durumu tahmini, orman yangını, deprem, toprak kayması vb. doğal afetlerin öngörülmesi ve olay anında çalışmaların yürütülmesi, trafik sıkışıklarını ve kazaları engelleme amaçlı olarak trafik simülasyonlarının oluşturulması, bir proje için en uygun konumun seçilmesi ve şehir planlamasının yapılması vb. birçok amaçla kullanılmaktadırlar.

Günümüzde İHA kullanımı hızla artmaktadır. Bunun nedenlerinden bazıları; düşük maliyetle üretilebilmeleri, bakım-onarım ve yakıt gibi masraflarının az olması, insanların yapamayacağı ya da yapmalarının tehlikeli olacağı görevleri yerine getirebilmeleri, hassas ve kaliteli veri üretebilmeleri, düşük emisyona sahip olmaları şeklinde sayılabilir (Yılmaz vd., 2018).

İHA'ların sinıflandırılması konusunda farklı görüşler bulunmaktadır. Literatürde İHA'ların sınıflandırılmasında iki görüşün ağır bastı̆̆ görülmüştür. Bunların birincisi; ağırlık, mesafe, hız, kanat sayısı vb. şeklindeki performans bazlı sınıflamadır. İkincisi ise, kullanım amaçlarına göre askeri, sivil, gözlem vb. bazlı yapılan sinıflamadır (Arjomandi, 2007)

Business Insider Intelligence'ın tahminlerine göre 2021 yılında dünya İHA satışları 12 milyar doları aşacaktır. Ayrıca 2016 yılından itibaren İHA satışlarının ortalama yıllık yüzde 7,6 oranında arttığı görülmüștür (Business Insider Intelligence, 2020). Bu verilerden anlaşılacağı üzere, İHA piyasası hızla büyümektedir. Türkiye'nin bu piyasadan yüksek pay alması hem ihracatını artırarak cari açığının azalmasına; hem de ekonomik büyümenin artmasına katkı verecektir.

Çalışmada İHA sınıflaması, ağırlık bazlı olarak yapılmıştır. Çalışmada İHA ihracatı incelendiği için, küresel ürün sinıflandırma sistemlerinden olan Uyumlaştırılmış Sistem (Harmonized System-HS) kullanılmıştır. Avrupa Komisyonuna göre IHHA'lar altı ürün grubu altında yer almaktadır (European Commision, 2017). Bu ürün grupları ve çalışmada yer alıp almadığına ilişskin bilgiler Șekil 1'de verilmiștir.
Tablo 1. HS Sınıflamasına Göre İHA'ların Dahil olduğu Ürün Grupları Tablosu

\begin{tabular}{|c|c|}
\hline Ürün Kodları ve İsimleri & $\begin{array}{l}\text { Çalışmada Yer } \\
\text { Alıp Almadığı }\end{array}$ \\
\hline $\begin{array}{l}\text { 880211- "Yüksüz ağırlığı } 2000 \text { kg'ı geçmeyen } \\
\text { helikopterler", }\end{array}$ & Yer Alıyor \\
\hline $\begin{array}{l}\text { 880212- "Yüksüz ağırlığı } 2000 \text { kg'ı ile } 15000 \text { kg } \\
\text { arasında olan helikopterler" }\end{array}$ & Yer Alıyor \\
\hline $\begin{array}{l}\text { 880220-Yüksüz ağırlı̆̆ı } 2000 \text { kg'ı geçmeyen } \\
\text { uçaklar ve diğer uçaklar }\end{array}$ & Yer Alıyor \\
\hline $\begin{array}{l}\text { 880230- "Yüksüz ağırlığı } 2000 \text { kg'ı ile } 15000 \text { kg } \\
\text { arasında olan uçaklar ve diğer uçaklar" }\end{array}$ & Yer Alıyor \\
\hline $\begin{array}{l}852580-\quad \text { "Televizyon kameraları, } \\
\text { kameralar ve video kamera kaydediciler" }\end{array}$ & Yer Almiyor \\
\hline $\begin{array}{l}\text { 950330- "Üç tekerlekli bisikletler, scooterlar, } \\
\text { pedallı arabalar ve benzeri tekerlekli oyuncaklar; } \\
\text { oyuncak bebek arabaları, bebekler; diğer } \\
\text { oyuncaklar, küçük boyutlu (ölçekli) modeller ve } \\
\text { benzer rekreasyon modelleri, çalışır veya } \\
\text { çalışmaz; her türden bulmaca" }\end{array}$ & Yer Almiyor \\
\hline
\end{tabular}

Çalışmada,

Avrupa

Komisyonunun sınıflandırmasına dahil olan iki ürün grubu analiz dışında tutulmuştur. Analize bahsi geçen iki ürün grubunun dâhil edilmemesinin nedeni bu ürün grupları içerisinde, İHA'larının payının düşük olacağının düşünülmesidir.

Çalışmanın amacl; Türkiye'nin İHA ihracatının uluslararası rekabet gücünün belirlenmesidir. Bu amaçla çalışmada rekabet gücü analizlerinde literatürde yaygın olarak kullanılan; Açıklanmış Karşılaştırmalı Üstünlük Endeksleri (Balassa Endeksleri), Açıklanmış Rekabet Üstünlügü Endeksleri (Vollrath Endeksleri) ve İhracatta Uzmanlaşma Endeksi (ES) kullanılmıştır.

Çalışmanın birinci kısmında; konuya ilişskin literatür taraması yer almaktadır. İkinci kısımda; İnsansız Hava Aracı başlığı altında İHA'lar ile ilgili kavramsal bilgiler verilmiștir. Üçüncü bölümde; Türkiye'nin Ürettiği İHA/SİHA'lar başlığı altında, Türkiye'nin ürettiği İHA ve SïHA'lar hakkında bilgiler verilmiştir. Çalışmanın dördüncü bölümünde çalışmada kullanılan yöntem ve endeksler açıklanmıştır. Beşinci bölümlerinde ise; analiz sonucunda elde edilen bulgular açıklanmıştır. Son olarak ise; sonuç bölümünde analiz bulguları toplulaştırılmış ve politika önerilerinde bulunulmuștur.

\section{LİTERATÜR}

Çalışmanın bu bölümünde, İHA'larla ilgili yapılmış olan akademik çalışmaların literatür taramasına yer verilmiștir. Özellikle son dönemlerde İHA'larla ilgili yapılmış olan akademik çalışmaların sayısının hızla artmış olduğu görülmüştür. Literatür taramasında, Türkiye'de İHA'lar ile yapılmış çalıșmalara ve İHA'ların uluslararası ticaretteki yerini araştıran çalışmalara yer verilmiştir.

Kahvecioğlu ve Oktal (2014) çalışmasında, Türkiye'nin geliştirmekte olduğu İHA'ları ve Türkiye'de İHA üretiminin geleceği analiz edilmiştir. Sonuç olarak, Türkiye'nin bağımsız İHA sistemlerini geliștirmesinin, üretim maliyetlerini düşüreceği ve böylece Türkiye'nin İHA kullanımında daha özgür hareket edebileceği ön görülmüştür. 
Kahveci ve Can (2017) çalışmasında, İHA'ların sivil kullanım alanları, amaçları ile Türkiye ve Dünya'daki mevzuata ilişkin durum tespiti yapılmıştır. Askeri amaçla kullanılan İHA'lar çalışmanın kapsamında yer almamıştır. Sonuç olarak; Türkiye ve Dünyada İHA'ların kötü amaçlarla kullanımının engellenmesi için tedbirler alınması gerektiği vurgulanmıştır. Fakat bu tedbirler alınırken İHA kullanımının kısıtlanmasına neden olunmaması gerektiği vurgulanmıştır.

Bakır (2019) çalışmasında, özellikle son yıllarda büyük gelişme gösteren ve bir ihracat kalemi haline gelen Türk İHA sektörü analiz edilmiştir. Sonuç olarak; savunma sanayinde dışa bağımlılığın azaltılması ve teknoloji üreticisi bir ülke olabilmek için İHA sektörünün son derece önemli olduğu vurgulanmıştır.

Yeşilay ve Macit (2019) çalışmasında, son dönemde büyük gelişme gösteren İHA’ların ekonomideki yeri analiz edilmeye çalışılmıştır. Sonuç olarak; İHA sektöründeki gelişmelerin günümüzde ve gelecekte ülke ekonomilerine olumlu etki yapacağı vurgulanmıștır.

Düz (2020) çalışmasında, Türkiye'nin İHA sektörünün tarihi, bugünü ve geleceği askeri, endüstriyel ve jeopolitik açıdan değerlendirilmiştir. Sonuç olarak; Türkiye'nin İHA'lar ile hem askeri kapasitesini artırdığı hem de dünyada İHA sektöründe rekabetçi bir ülke olduğu belirtilmiștir.

Türk (2020) çalışmasında, Türkiye'nin İHA endüstrisi değerlendirilmiştir. Sonuç olarak, Türkiye'nin İHA endüstrisinde görülen sorunlar ve çözüm önerileri sunulmuş özellikle yapay zekanın geliştirilmesinin önemi vurgulanmıștır.

Şen ve Akarslan (2020) çalışmasında, İHA'ların saldırı potansiyeli ve İHA'lara karşı alınabilecek tedbirler analiz edilmiştir. Sonuç olarak; Türkiye üzerinden örnekler verilerek, İHA’ların saldırı potansiyelinin yüksek olduğu ve İHA'lara karşı savunma tedbirlerinin alınmasının özellikle terörle mücadele kapsamında son derece önemli olduğu vurgulanmıştır.

Literatür taramasında, Türkiye'nin İHA ihracat ve ithalatını analiz eden ve diș ticaret analizlerinde yaygın olarak kullanılan endekslerle yapılmış bir çalışmanın bulunmadığı görülmüştür. Çalışmanın bu boşluğu doldurma anlamında literatüre katkı vereceği düşünülmektedir.

\section{INSANSIZ HAVA ARAÇLARI}

İnsansız hava aracının, uzlașılmış bir tanımı bulunmamaktadır. Yapılmış genel tanımlara bakılarak, İHA'lar şöyle tanımlanabilir; içinde bir pilot bulunmayan, kullanım amacına göre üzerinde farklı donanımlar taşıyabilen, belli bir yönetim merkezinde yönetilen ya da önceden belirlenmiş bir güzergâh üzerinde kendiliğinden hareket edebilen hava araçlarıdır (Akkamış \& Çalışkan, 2020).

\section{1. İHA'ların Tarihi Gelişimi}

İlk İHA'nın ne zaman kullanıldığına ilișkin bir uzlaşı bulunmamaktadır. Fakat İHA'ların ilk örneklerinin, 1766 yılında Henry Cavendish tarafindan hidrojen gazının keşfi ile ortaya çıkma şansı buldukları söylenebilir. İHA'ların bilimsel anlamda ilk kullanımı, Fransız Fizikçi
Jean Baptiste Biot ve Fransız Kimyacı Joseph Louis Gay Lussac'ın 1804 yılında gerçekleştirdikleri, havanın bileşimi ve dünyanın manyetik alanı üzerine yaptıkları çalışmalar sırasında gerçekleştirilmiştir (Türkseven vd., 2016).

İHA'ların askeri anlamda ilk kullanımı; keşif amacıyla 1793 yılında ABD'de gerçekleştirilmiştir. 18611865 yılları arasında yaşanan Amerikan İç Savaşı'nda İHA'lar keşif görevi yapmışlardır. İHA'ların saldırı amacıyla ilk kullanımı; 1849 yılında AvusturyaMacaristan İmparatorluğu tarafından Venedik şehrine gönderilen zaman ayarlı bombalar taşıyan balonlar ile gerçekleștirilmiştir (Yardımcl, 2019).

Bugünkü anlamda ilk İHA, 6 Mart 1918'de ABD'de kullanılmıștır. İlk İHA'ya, Curtis N-9 Aerial Torpedo adı verilmiştir ve 6 Mart 1918 tarihinde havalandırılmış, 1000 yarda (yaklaşık 914 metre) uçuş gerçekleştirmiş ve belirlenen yer ve zamanda yere inmiştir (Erdağ, 2020).

Daha sonraki dönemlerde, İHA'ların geliştirilmesi askeri amaçlar güdülerek gerçekleştirilmiştir. İHA'lar Vietnam (1964-1972), İsrail-Lübnan Çatışmaları (1982) ve Birinci ve İkinci Körfez savaşlarında aktif olarak kullanılmışlardır (Demir vd., 2015). İlk İHA filosu İsrail tarafından 200. Hava Filosu adıyla 1971 yılında kurulmuștur.

Günümüzde ise, İHA'lar askeri ve sivil olmak üzere birçok alanda kullanılmaktadır. İHA endüstrisi uzman kuruluşlarından olan Teal Group to the Association for Unmanned Vehicle Systems International (AUVSI) tahminlerine göre, küresel İHA pazarının büyüklügü 6 ila 12 milyar dolar civarındadır ve yıllık olarak yüzde 5-10 arasında büyümektedir.

\section{2. İHA'ların Avantajları}

İHA kullanımının birçok avantajı mevcuttur. Bunlar; kullanım amacına yönelik istenen araç-gereçle donatılabilme, hayati tehlikenin olduğu ve riskli görevleri yerine getirebilme, alçak irtifada uçarak detaylı bilgiler edinebilme, düşük maliyetli olma, maliyetli olabilecek yatırımları düșük maliyetlerle yerine getirebilme (3D modelleme) vb. şeklinde sayılabilir.

Askeri alanda kullanılan İHA ve SİHA'ların avantajları ise, pilot kaybı riskinin olmaması, insan kaynaklı kısıtlamaların olmaması (çalışma saati, uyku gereksinimi vb.), savaş uçaklarına kıyasla maliyet, yakıt ve bakım-onarım masraflarının düşük olması, boyutlarının ufak olmasından dolayı düşman radarları tarafından zor tespit edilmeleri şeklinde sayılabilir (Nişancı vd., 2018).

\section{3. İHA'ların Dezavantajları}

İHA kullanımının birçok avantajı olduğu gibi bazı dezavantajları da bulunmaktadır. Bunlar şöyle siralanabilirler;

İlk olarak; İHA'ların havada kalma süreleri sınırlıdır. Bu durum özellikle geniş alanlarda yapılan faaliyetlerde kimi zaman bir dezavantaj oluşturmaktadır. İkincisi; İHA'lar rüzgâr ve yağıştan olumsuz etkilenmektedir ve bu durum yapılan görevin kalitesini etkilemektedir. Üçüncüsü; İHA'ların etkin kullanılabilmesi için belli bir elektronik iletişim ve veri akışının sağlanması 
gerekmektedir. Bu akışın yer yer çevresel veya savunma tedbirleri nedeniyle kesilmesi olumsuz sonuçlara neden olabilmektedir (Dikmen, 2015). Dördüncüsü; İHA'lar terör örgütleri ya da kötü niyetli bireylerin elinde casusluk, saldırı gibi hizmetlerde kullanılabilirler. Beşincisi; İHA'ların etkin şekilde kullanılabilmesi için eğitimli kullanıcılara ihtiyaç duyulmaktadır. Bunun için uzun süren ve maliyetli eğitimlerin verilmesi gerekmektedir. Son olarak; kimi uzmanlara göre İHA'lar yazılım ve donanım zaafları taşımaktadırlar ve siber saldırılara açıktırlar, bu yüzden İHA'ların güvenilirlikleri sorgulanmaktadır.

\subsection{Türkiye'nin İHA Geliştirme Süreci}

Teknolojideki hızlı gelișme ile, askeri teknoloji de bundan etkilenmiștir. Günümüzde insansız sistemler savaş alanlarında daha yaygın olarak kullanılmaya bașlanmıștır. İHA teknolojisinin askeri anlamda gelişimi de aslında askeri teknolojinin bu gelişiminin yansımasıdır. Özellikle insansız sistemlerin terörle mücadelede başarı şansını artıracağı düşünülmektedir.

Türkiye uzun yıllardır terörizmin hedefinde olan bir ülkedir. $\mathrm{Bu}$ nedenle Türkiye'de İHA teknolojisinin gelişimi askeri amaçlar ağırlıklı olarak gerçekleşmiştir. TSK'da kullanılan ilk İHA, 1989 yılında kullanılmaya başlayan Meggitt firması tarafından üretilmiş olan, Banshee sistemidir. Türkiye'nin yerli İHA üretmek için geliştirdiği ilk proje olan İHA-X1-Şahit projesi Mart 1990 tarihinde başlatılmıştır (Aksan, 2020). X1-Şahit, İHA'sından iki adet üretilmesine ve başarıyla uçurulmasına rağmen bütçe sorunlarından dolayı seri üretime geçilmemiştir. 1993 yılında Almanya tarafından 5 adet CL-89 İHA'sı Türkiye'ye hibe edilmiştir. Fakat lojistik sıkıntılar ve yaşanan kazalar nedeniyle bu İHA'lar envanterden çıkarılmıştır. 1994 yılında Türkiye ABD'den GNAT-750 İHA'larını ithal etmiş ve bu İHA'lar 1994-1998 döneminde aktif görevde kullanılmışlardır. TSK'nın ihtiyacı olan İHA'ların ithal edilmesine paralel olarak, yerli İHA üretebilmek için adımlar atılmaya başlanmıştır. Bunların sonucu olarak Türk Havacılık ve Uzay Sanayii (TUSAŞ) tarafından sırasıyla; Turna-Keklik (1996), Pelikan-Martı (2003), Öncü (2008), Şimşek (2012) ve ANKA (2010) insansız hava araçları üretilmiştir.

Yerli İHA üretmeyi amaçlayan Türkiye, ihtiyaçlar doğrultusunda, 2005 yılında İsrail'den bir adet Heron İHA'sını 4 milyon dolar bedelle kiralamıștır. 2007 yılında üç adet daha Heron kiralanmasına rağmen, bu İHA'lardan istenen verim alınamamış hatta üç tanesi düșmüștür. Buna rağmen, Türkiye 2008 yılında on adet Heron'u 188 milyon dolar bedelle satın almıştır (Yanarocak, 2020). Teknik özellikler açısından ABD menşeili Predator İHA'sı, Heron'a göre daha gelişmiştir. Fakat İsrail'in Aselsan tarafından geliştirilen Aselflir 300T'yi (Elektrooptik keşif, gözetleme ve hedefleme sistemi) Heron'lara entegre etmeyi kabul etmesi, Türkiye'nin Heron'ları tercih etmesinde önemli bir etmen olmuștur. Sonraki dönemlerde İsrail ile yaşanan Mavi Marmara olayının da etkisiyle Türkiye, İHA konusunda yerli ve milli kaynaklara yönelmeye başlamıștır.

İsrail ile İHA konusundaki ilişkiler sürerken, 2007 yılında Baykar tarafından üretilen Bayraktar Mini İHA, TSK envanterine girmiștir. Bu İHA 2012 yılında Katar'a ihraç edilerek, ihracatı gerçekleştirilen ilk yerli İHA olmuştur. Daha sonrasında Baykar tarafından, Malazgirt (2009), Bayraktar TB2 (2014) üretilmiștir. Buna ek olarak, Bayraktar Akıncı ve Bayraktar DİHA'nın üretim ve geliştirme süreçleri devam etmektedir. Özellikle Bayraktar TB2'ler, 2015 yılında silah sistemleri ile donatılmışlar ve Türkiye'nin gerçekleștirmiş olduğu Fırat Kalkanı (2016), Zeytin Dalı (2018), Barış Pınarı (2019) ve Bahar Kalkanı (2020) harekâtlarında etkin şekilde kullanılmışlardır (Urcosta, 2020). Bu sayılanlar dışında, Türkiye'de yerli firmalarca üretilmiş olan birçok İHA/ SİHA'lar bulunmaktadır. Bunlar Tablo 2'de verilmiştir.

Tablo 2. Türkiye'nin Ürettiği İHA/SİHA'lar

\begin{tabular}{|c|c|c|c|c|}
\hline $\begin{array}{c}\text { İHA / SİHA } \\
\text { Adı } \\
\end{array}$ & $\begin{array}{l}\text { Üreti } \\
\text { m Yılı }\end{array}$ & $\begin{array}{l}\text { Üretici } \\
\text { Firma }\end{array}$ & $\begin{array}{c}\text { Ağırlık } \\
\text { (kg) }\end{array}$ & $\begin{array}{c}\text { Uçuş } \\
\text { Süresi }\end{array}$ \\
\hline Turna & 1995 & TUSAȘ & 75 & $90 \mathrm{dk}$ \\
\hline Bayraktar Mini & 2007 & Baykar & 4,5 & $60-80 \mathrm{dk}$ \\
\hline Malazgirt & 2009 & Baykar & 12 & 2 saat \\
\hline Şimşek & 2009 & TUSAȘ & 75 & 1 saat \\
\hline Anka & 2010 & TUSAȘ & 1600 & 24 saat \\
\hline Karayel & 2014 & Vestel & 550 & 20 saat \\
\hline Bayraktar TB2 & 2015 & Baykar & 650 & 27 saat \\
\hline Alpagu & 2017 & STM & 3,7 & $10 \mathrm{dk}$ \\
\hline Altınay X-4 & 2017 & Altınay & $3,6-20$ & 1,5 saat \\
\hline Togan & 2017 & STM & 7 & $50 \mathrm{dk}$ \\
\hline Uçankaya 30 & 2017 & Uçankaya & $19-30$ & - \\
\hline Uçankaya 60 & 2017 & Uçankaya & $45-60$ & - \\
\hline Serçe-I & 2018 & Aselsan & 6,5 & $30 \mathrm{dk}$ \\
\hline ARI-1T & 2018 & Aselsan & 3 & 2 saat \\
\hline Kargu & 2018 & STM & 7 & $30 \mathrm{dk}$ \\
\hline Tetron & 2018 & Otonom ek. & - & - \\
\hline Kargu-2 & 2019 & STM & - & - \\
\hline Songar & 2019 & Asisguard & 45 & $20 \mathrm{dk}$ \\
\hline Mius Mini & 2019 & Aselsan & 8 & 2 saat \\
\hline Albatros & 2019 & Altınay & $195-370-630$ & 1 saat \\
\hline Sumru & 2019 & Altınay & 120 & 6 saat \\
\hline Kartal & 2019 & Altınay & 40 & $25 \mathrm{dk}$ \\
\hline Doğan & 2019 & Altınay & 40 & $25 \mathrm{dk}$ \\
\hline
\end{tabular}

Türkiye'nin geliştirme aşamasında olduğu İHA/SİHA'ların listesi Tablo 3'te verilmiştir. Yıl sütununda, geliştirilen sistemin seri üretime geçeceği tahmin edilen yıl yer almaktadır (Aksan, 2020).

Tablo 3. Türkiye'nin Geliștirmekte İHA/SİHA'lar

\begin{tabular}{|c|c|c|c|c|}
\hline İHA/ SİHA Adı & Yll & Firma & $\begin{array}{c}\text { Ağırlığı } \\
\text { (kg) }\end{array}$ & $\begin{array}{r}\text { UçuŞ } \\
\text { Süresi } \\
\end{array}$ \\
\hline & 202 & & & \\
\hline Aksungur & $\begin{array}{l}1 \\
202\end{array}$ & TUSAȘ & 1800 & 24 saat \\
\hline Akıncı & 1 & Baykar & 5500 & 24 saat \\
\hline Bayraktar & 202 & & & \\
\hline DİHA & $\begin{array}{l}1 \\
202\end{array}$ & Baykar & 30 & 12 saat \\
\hline MİUS & 3 & Baykar & 3500 & 4-5 saat \\
\hline
\end{tabular}

Türk Silahlı Kuvvetleri bünyesinde İHA kullanan bazı birimler oluşturulmuştur. Bunlar, Batman'da konuşlanmış olan 14. İnsansız Uçak Sistemleri Üs Komutanlığı, Elazığ'da konuşlanmış olan Elâzığ Taktik İHA Birlik Komutanlığı ve Çanakkale'de bulunan 313. Deniz İHA-S İnsansız Hava Aracı Filo Komutanlı̆̆ olarak sayllabilirler. 
Türkiye, İHA üretimi konusunda geldiği nokta ile ihracatçı konuma yükselmiştir. Türkiye'nin gerçekleștirmiş olduğu İHA ihracatlarının, ülke, gerçekleşme yılı, model ve adet bilgileri Tablo 4'te verilmiştir.

Tablo 4. Türkiye'nin İHA İhracatı

\begin{tabular}{|c|c|c|c|}
\hline Ülke & Yil & Model & Adet \\
\hline Katar & 2012 & Bayraktar Mini & 20 \\
\hline Suudi Arabistan & 2017 & Karayel & $\begin{array}{l}\text { Teknoloji } \\
\text { Transferi }\end{array}$ \\
\hline Libya & 2019 & Bayraktar TB2 & - \\
\hline Katar & 2019 & Bayraktar TB2 & 6 \\
\hline Ukrayna & 2019 & Bayraktar TB2 & 6 \\
\hline Azerbaycan & 2020 & Bayraktar TB2 & 6 \\
\hline Tunus & 2020 & ANKA & 3 \\
\hline
\end{tabular}

Türkiye'nin İHA/SİHA üretmesi birçok fayda sağlamaktadır. Bunlar,

1. İHA üretimi maliyet avantajını beraberinde getirmiştir. Örneğin; İsrail'den alınan Heron İHA'ları için birim başına, Türkiye 18 milyon dolar ödemiştir. Yerli kaynaklarla üretilmiș olan Bayraktar TB2'nin ise birim fiyatı 4 milyon dolar civarındadır.

2. İlerleyen yıllarda savaş alanlarında daha fazla insansız aracın görev alacağı tahmin edilmektedir. Türkiye, İHA üretimi ile aslında gelecekte üretebileceği diğer insansız araçlar için bilgi, tecrübe ve sermaye birikimi sağlamaktadır.

3. İHA/SİHA'ların önem kazanması ile bu araçların ihracatının daha da artacağı düşünülmektedir. Türkiye İHA ihracat pazarından daha yüksek paylar alarak, dış ticaret açığını azaltma ve ekonomik büyümesini artırma şansı yakalayabilir.

Türkiye'de İHA'larla ilgili prosedürler, Sivil Havacılık Genel Müdürlüğü tarafından 22 Nisan 2016 tarihinde yayınlanmış olan "İnsansız Hava Aracı Sistemleri Talimatı-SHT-İHA" ile düzenlenmiștir. Türkiye'de 2019 yılı itibariyle, İHA pilot lisansına sahip kişi sayısı 52.120, İHA sayısı ise 34.150'dir (Sivil Havacılık Genel Müdürlüğü, 2020).

\section{YÖNTEM}

Küreselleşmenin artması ile ülkelerin dış ticarete konu olan ürünlerde rekabet güçlerini belirlemeleri önem kazanmıştır. Rekabet gücü, bir ülkenin ya da firmanın belli bir mal veya hizmette uluslararası piyasalardaki durumudur.

Rekabet gücünün belirlenmesi için çeşitli dış ticaret endeksleri bulunmaktadır. Çalışmada yer alan endeksler şu şekildedir;

\subsection{Açılklanmış Karşılaştırmalı Üstünlük} Endeksleri (Revealed Comparative Advantage IndexRCA)

1965 yılında Balassa, kendi adıyla da anılan Açıklanmış Karşılaştırmalı Üstünlükler (RCA) endeksini geliştirmiştir (Seymen, 2009, s. 236). Balassa endeksinin amacl, ilgili mal ya da endüstri için, ülkenin karşılaştırmalı üstünlüğe sahip olup olmadığını belirlenmesidir. Denklem 1'de RCA2 endeksi görülmektedir. Denklem 1'de X ihracatı, i ülkeyi, j mal veya endüstriyi, $t$ mal veya endüstri grubunu ve $n$ ülke veya ülke grubunu temsil etmektedir. Endeks değerinin 1'den büyük olması, ülkenin bahsi geçen ürün veya endüstride açıklanmış karşılaştırmalı üstünlüğü olduğunu göstermektedir. Endeks değeri 1'den küçük ise, ülkenin bu mal veya endüstri grubunda açıklanmış karşılaştırmalı üstünlüğünün olmadığını göstermektedir.

$\operatorname{RCA2}=\frac{X_{i j} / X_{i t}}{X_{n j} / X_{n t}}$

RCA2 endeksi, ithalatı analize dahil etmediği için eleştirilmiştir. Eleştiriler sonucunda, endeks revize edilmiş ve ithalatı da analize dahil eden Açıklanmış Karşlaştırmalı Üstünlük Endeksi (RCA3) oluşturulmuştur. RCA3 endeksinde bulunan değerler eğer 1'den büyükse o ürün veya ürün grubunda karşılaştırmalı üstünlük olduğu düşünülmektedir. RCA3 endeksi aşağıdaki gibi formüle edilir. Denklem 2'de RCA3 endeksi görülmektedir. Denklem 2'de Xij i ülkesinin j malı ihracatını, Xit i ülkesinin t malı ihracatını, Mij i ülkesinin j malı ithalatını, Mit i ülkesinin t malı ithalatını temsil etmektedir. Endeks değerinin 1'den büyük olması, ülkenin bahsi geçen ürün veya endüstride açılanmıș karşılaştırmalı üstünlüğü olduğunu göstermektedir. Endeks değeri 1'den küçük ise, ülkenin bu mal veya endüstri grubunda açıklanmış karşılaştırmalı üstünlüğünün olmadığını göstermektedir.

$\mathrm{RCA3}=\frac{X_{i j} / X_{i t}}{M_{i j} / M_{i t}}=\frac{X_{i j} / M_{i j}}{X_{i t} / M_{i t}}$

\subsection{Açıklanmış Rekabet Üstünlük Endeksleri (Revealed Competitiveness-RC)}

Balassa endeksine alternatif olarak Vollrath 1991 yılında, rekabet gücünü açıklamaya yönelik olarak açıklanmış rekabet üstünlük endekslerini oluşturmuştur. $\mathrm{Bu}$ yöntem sırasıyla nispi ticaret üstünlüğü (relative trade advantage-RTA), nispi ihracat üstünlüğü (relative export advantage-RXA), nispi ithalat üstünlüğü (relative import advantage-RMA) bileşenlerinden oluşmaktadır. Nispi ticaret üstünlüğü (RTA), nispi ihracat üstünlüğünden (RXA) nispi ithalat üstünlüğü (RMA) endeks değerlerinin farkından oluşmaktadır. Bu endekslerin pozitif değer alması, rekabetçi bir avantajın varlığını; negatif değer alması ise rekabetçi bir dezavantajın varlığını göstermektedir. Balassa endeksiyle, Vollrath endeksi arasındaki temel bir fark bulunmaktadır. Bu fark, Vollrath endeksi hesaplanırken iki kere hesaplamadan kaçınmak için rekabet gücü analiz edilen ülkenin ticaret verileri, dahil olduğu ülke grubunun ticaret verilerinden çıkartılıyor olmasıdır.

\subsubsection{Nispi İhracat Üstünlüğü Endeksi (Revealed Export Competitiveness-RXA)}

Nispi ihracat üstünlüğü endeksi (RXA), belirli bir mal grubunda herhangi bir ülkenin, küresel pazarda sahip olduğu ihracat payının diğer bütün mal gruplarındaki dünya ihracatındaki payına oranlanması olarak ifade edilmektedir (Vollrath, 1991, s. 270). 
Denklem 3'te RXA endeksi görülmektedir. Denklem 3'te Xij i ülkesinin j malı için ihracat değeri, Xit i ülkesinin toplam ihracat değerini, Xwj j malı için toplam dünyada gerçekleșen ihracat değerini, Xwt ise dünyada bütün mallar için gerçekleşen ihracat değerini temsil etmektedir.

$$
R X A_{i j}=\left(\frac{X_{i j}}{\frac{X_{i t}}{X_{i j}}}\right) /\left(\frac{X_{w j}-X_{i j}}{X_{w t}-X_{i t}}\right)
$$

\subsubsection{Nispi İthalat Üstünlüğü Endeksi (Revealed Import Competitiveness-RMA)}

Nispi ithalat üstünlüğü endeksi (RMA), belirli bir mal grubunda herhangi bir ülkenin, küresel ticarette sahip olduğu ithalat payının diğer bütün mal gruplarında dünya ithalatındaki payına oranı olarak ifade edilmektedir. Denklem 4'te RMA endeksi görülmektedir. Denklem 4'te Mij i ülkesinin j malı için ithalat değerini, Mit i ülkesinin toplam ihracat değerini, Mwj j malı için toplam dünyada gerçekleşen ithalat değerini ve Mwt dünyada bütün mallar için gerçekleșen ithalat değerini temsil etmektedir.

$$
R M A_{i j}=\left(\frac{M_{i j}}{\frac{M_{i t}}{M_{i j}}}\right) /\left(\frac{M_{w j}-M_{i j}}{M_{w t}-M_{i t}}\right)
$$

\subsubsection{Nispi Ticaret Üstünlüğü Endeksi (Revealed Trade Competitiveness-RTA)}

Denklem 5'te Nispi ticaret üstünlüğü endeksi (RTA) endeksinin nasıl hesaplandığı görülmektedir. Nispi ticaret üstünlüğü endeksi (RTA), nispi ihracat üstünlüğü endeksinden (RXA) nispi ithalat üstünlüğü endeksinin (RMA) çıkarılması sonucunda elde edilmektedir. Analiz sonucunun pozitif değer alması, ülkenin o ürün grubunda rekabet gücünün yüksek olduğu, negatif bir değer alması ise rekabet gücünün düşük olduğu şeklinde yorumlanır.

$$
R T A_{i j}=R X A_{i j}-R M A_{i j}
$$

Vollrath endeksi (RC- RTA) rekabet gücünün ölçülmesinde, Balassa endekslerine (RCA) göre daha isabetli sonuçlar vermektedir. Bunun nedeni; endekste ihracat ve ithalat verilerinin beraber kullanılmasıdır. Ancak RTA ve RC endeksleri bazı kısitlamalara da sahiptir. Özellikle iki yanlı ticaretin söz konusu olmadığı durumlarda (ithalat ya da ihracat sifırsa), endekslerinin uygulanması sınırlı kalacaktır (Şimşek \& Sadat, 2009).

\section{3 İhracatta Uzmanlaşma Endeksi (Export Specialization Index-ES)}

$\mathrm{Bu}$ endeks ülkelerin sadece kendi ticaret performanslarını dikkate almaktadır. ES endeksi, bir ülkenin belli bir ürün ya da ürün grubundaki ihracat ve ithalat verileri kullanılarak hesaplanmaktadır.

$\mathrm{ES}=\frac{X_{i j}-M_{i j}}{X_{i t}+M_{i t}}$
Denklem 6'da ES endeksi görülmektedir. Denklem 6'da Xij i ülkesinin j malı ihracatını, Mij i ülkesinin j malı ithalatını temsil etmektedirler. Endeks değeri pozitif ise ülkenin o ürüne ihracatında uzmanlaştığını, negatif ise ihracatta uzmanlaşmanın söz konusu olmadığı şeklinde yorumlanır. Endeks -1 ile +1 arasında değerler almaktadır.

\section{BULGULAR}

Çalışma kapsamında 4 adet ürün grubu ayrı ayrı ve toplu olarak incelenmiștir. Grafik yoluyla yapılan analizlerde birim olarak milyon ABD doları kullanılmıştır. Pay tablolarında ise yüzdelik oranlar yer almaktadır. Endeks tablolarında ise değerler endeks değerlerini temsil etmektedir. Bazı tablolarda 2020 yılına ilişkin analizler gerçekleştirilememiştir. Bunun nedeni henüz 2020 yılına ilişkin dış ticaret verilerinin tam olarak sağlanmamasıdır.

Türkiye'nin toplam İHA ihracat ve ithalat verileri tablosu Şekil 1'de verilmiştir. Şekle göre, 2002 ile 2018 yılları arasında Türkiye'nin İHA'larda dış ticaret açığı verdiği görülmüștür. 2019 ve 2020 yıllarında ise Türkiye'nin İHA ticaretinde dış ticaret fazlası verdiği görülmektedir.

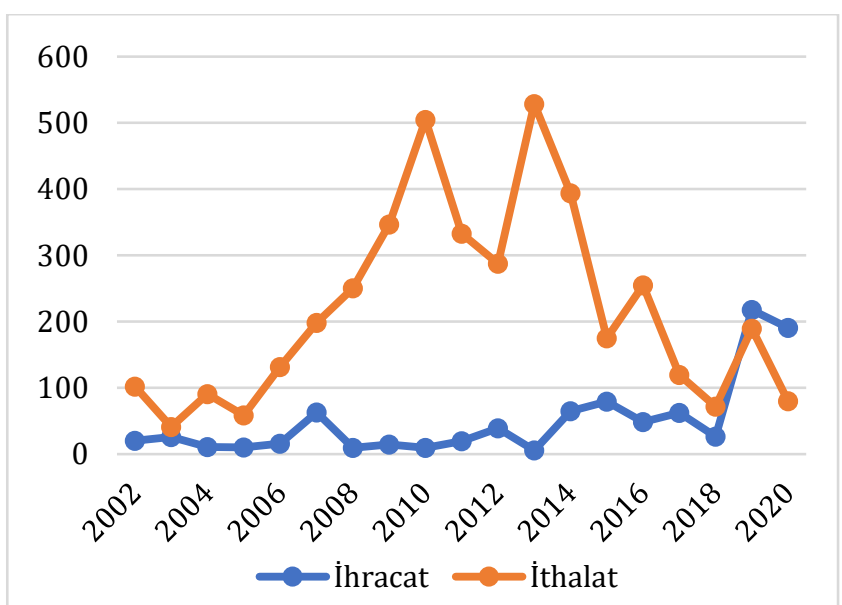

Şekil 1. Türkiye'nin İHA İhracat İthalat Verileri Tablosu

Çalışma kapsamında incelenen 4 ürün grubunun ve bunların toplamlarının, Dünyadaki aynı ürün ve ürün grubu ihracat ve ithalatı içindeki pay tablosu Tablo 5'te verilmiştir. İhracata bakıldığında, 880220 kodlu (Yüksüz ağırlığı 2000 kg'ı geçmeyen uçaklar ve diğer uçaklar) ürün grubu dışındaki ürün gruplarında, Türkiye'nin dünya ihracatından aldığı payın düşük olduğu görülmüştür. 880220 kodlu ürün grubunda ise 2019 yılında Türkiye'nin dünya ihracatının yüzde 21,01'ini gerçekleştirdiği görülmüştür. Ürün gruplarının toplamına bakıldığında ise, Türkiye'nin yıllar itibariyle İHA ihracatından daha yüksek paylar almaya başladığı söylenebilir. 2019 yllında ise Türkiye, dünya İHA ihracatının yüzde 1,43'ünü gerçekleştirmiştir. 
Tablo 5. Dünya İHA Ticaretinde Türkiye'nin Payı

\begin{tabular}{|c|c|c|c|c|c|c|c|c|c|c|c|}
\hline İhracat & 880211 & 880212 & 880220 & 880230 & Toplam & İthalat & 880211 & 880212 & 880220 & 880230 & Toplam \\
\hline 2002 & 0,14 & 0,04 & 0,01 & 0,14 & 0,12 & 2002 & 0,00 & 4,70 & 0,14 & 0,32 & 0,79 \\
\hline 2003 & 0,03 & 0,02 & 0,11 & 0,21 & 0,17 & 2003 & 0,00 & 3,81 & 0,08 & 0,00 & 0,30 \\
\hline 2004 & 0,09 & 0,23 & 0,02 & 0,05 & 0,07 & 2004 & 0,46 & 2,41 & 0,11 & 0,49 & 0,64 \\
\hline 2005 & 0,24 & 0,26 & 0,00 & 0,04 & 0,08 & 2005 & 0,49 & 0,41 & 3,26 & 0,27 & 0,44 \\
\hline 2006 & 0,14 & 0,24 & 0,15 & 0,03 & 0,08 & 2006 & 0,83 & 0,56 & 0,61 & 0,67 & 0,66 \\
\hline 2007 & 0,00 & 0,13 & 0,03 & 0,33 & 0,26 & 2007 & 0,03 & 1,60 & 0,19 & 1,06 & 1,01 \\
\hline 2008 & 0,00 & 0,01 & 0,01 & 0,05 & 0,04 & 2008 & 0,42 & 2,66 & 0,46 & 0,49 & 0,70 \\
\hline 2009 & 0,00 & 0,00 & 0,05 & 0,17 & 0,10 & 2009 & 3,42 & 2,02 & 1,13 & 1,65 & 1,81 \\
\hline 2010 & 0,00 & 0,02 & 0,05 & 0,10 & 0,07 & 2010 & 0,74 & 6,23 & 8,74 & 1,60 & 3,10 \\
\hline 2012 & 0,06 & 0,14 & 0,42 & 0,33 & 0,25 & 2012 & 0,21 & 3,60 & 0,36 & 1,55 & 1,83 \\
\hline 2013 & 0,00 & 0,04 & 0,01 & 0,03 & 0,03 & 2013 & 0,98 & 5,09 & 1,16 & 2,52 & 3,06 \\
\hline 2014 & 0,46 & 0,13 & 0,04 & 0,42 & 0,31 & 2014 & 2,30 & 2,48 & 1,31 & 2,29 & 2,31 \\
\hline 2015 & 0,39 & 0,07 & 0,06 & 0,62 & 0,39 & 2015 & 0,09 & 1,64 & 0,60 & 0,77 & 0,94 \\
\hline 2016 & 0,16 & 0,02 & 0,03 & 0,42 & 0,25 & 2016 & 1,19 & 0,61 & 2,14 & 2,16 & 1,53 \\
\hline 2017 & 0,54 & 0,23 & 0,02 & 0,46 & 0,36 & 2017 & 0,81 & 0,96 & 0,39 & 0,59 & 0,67 \\
\hline 2018 & 0,01 & 0,38 & 0,10 & 0,10 & 0,18 & 2018 & 0,24 & 1,13 & 0,16 & 0,24 & 0,43 \\
\hline 2019 & 0,42 & 0,19 & 21,01 & 0,20 & 1,43 & 2019 & 0,19 & 4,68 & 0,51 & 0,07 & 1,07 \\
\hline
\end{tabular}

İthalata bakıldığında, 880211, 880220 ve 880230 kodlu ürün grubunda bazı yıllarda Türkiye'nin ithalat payının arttığı görülmekle beraber özellikle son yıllarda bir düşüş yaşandığı görülmüştür. 880212 (Yüksüz ağırlığı 2000 kg'ı ile 15000 kg arasında olan helikopterler) kodlu ürün grubunda ise Türkiye'nin dünya ithalatında genel olarak yüzde 1'in üzerinde paya sahip olduğu söylenebilir. Ürün gruplarının toplamlarına bakıldığında ise genel anlamda Türkiye'nin dünya ithalatı içindeki payının azaldığı görülmüştür.

880211 kodlu (Yüksüz ağırlı̆̆ 2000 kg'ı geçmeyen helikopterler) ürün grubu için hesaplanmış olan endeks değerleri tablosu Tablo 6'da verilmiştir. RCA2 endeksinde, incelenen yıllar itibariyle Türkiye'nin karşılaştırmalı üstünlüğünün bulunmadığı görülmüștür. RCA3 endeksinde 2003, 2015 ve 2019 yılları dişında bir karşılaştırmalı üstünlüğe rastlanmamıştır. İnceleme dönemde genel olarak, nispi ithalat üstünlüğü endeksinin (RMA), nispi ihracat üstünlüğü endeksinden (RXA) yüksek olduğu görülmüştür. $\mathrm{Bu}$ nedenle nispi ticaret endeksi (RTA) negatif değerler almıștır. Bu Türkiye'nin 880211 kodlu ürün grubunda rekabet gücünün düşük olduğu şeklinde yorumlanmaktadır. İhracatta uzmanlaşma endeksine bakıldığında (ES) incelenen dönemlerde genellikle negatif değerler aldığı görülmüștür. Buradan Türkiye'nin ihracatta 880211 kodlu ürün grubunda uzmanlaşmadığı sonucunu çıkartılmıştır.

Tablo 6. 880211 Kodlu Ürün Grubu İçin Hesaplanan Endeks Değerleri

\begin{tabular}{lllllll}
\hline \multicolumn{7}{c}{$\mathbf{8 8 0 2 1 1}$} \\
\hline $\mathbf{2 0 0 2}$ & RCA2 & RCA3 & RXA & RMA & RTA & ES \\
$\mathbf{2 0 0 3}$ & 0,04 & - & 0,25 & 0,00 & 0,25 & 1,00 \\
$\mathbf{2 0 0 4}$ & 0,13 & 0,16 & 0,04 & 0,00 & 0,04 & 0,80 \\
$\mathbf{2 0 0 5}$ & 0,34 & 0,58 & 0,13 & 0,44 & $-0,31$ & $-0,81$ \\
$\mathbf{2 0 0 6}$ & 0,20 & 0,42 & 0,34 & 0,44 & $-0,10$ & $-0,46$ \\
$\mathbf{2 0 0 7}$ & 0,00 & 0,00 & 0,20 & 0,73 & $-0,52$ & $-0,59$ \\
$\mathbf{2 0 0 8}$ & 0,00 & 0,00 & 0,00 & 0,02 & $-0,02$ & $-1,00$ \\
$\mathbf{2 0 0 9}$ & 0,00 & 0,00 & 0,00 & 3,16 & $-0,34$ & $-1,00$ \\
$\mathbf{2 0 1 0}$ & 0,00 & 0,00 & 0,00 & 0,61 & $-0,61$ & $-1,00$ \\
$\mathbf{2 0 1 1}$ & 0,00 & 0,00 & 0,00 & 0,13 & $-0,13$ & $-1,00$ \\
$\mathbf{2 0 1 2}$ & 0,07 & 0,35 & 0,07 & 0,16 & $-0,09$ & $-0,63$ \\
$\mathbf{2 0 1 3}$ & 0,00 & 0,01 & 0,00 & 0,75 & $-0,74$ & $-0,99$ \\
$\mathbf{2 0 1 4}$ & 0,56 & 0,26 & 0,56 & 1,85 & $-1,29$ & $-0,71$ \\
$\mathbf{2 0 1 5}$ & 0,45 & 3,30 & 0,45 & 0,07 & 0,38 & 0,39 \\
$\mathbf{2 0 1 6}$ & 0,18 & 0,14 & 0,18 & 0,98 & $-0,80$ & $-0,81$ \\
$\mathbf{2 0 1 7}$ & 0,61 & 0,69 & 0,61 & 0,62 & $-0,01$ & $-0,36$ \\
$\mathbf{2 0 1 8}$ & 0,01 & 0,03 & 0,01 & 0,21 & $-0,20$ & $-0,95$ \\
$\mathbf{2 0 1 9}$ & 0,44 & 1,91 & 0,44 & 0,17 & 0,26 & 0,24 \\
$\mathbf{2 0 2 0}$ & - & 0,8912 & - & - & - & $-0,19$ \\
\hline
\end{tabular}

Tablo 7. 880212 Kodlu Ürün Grubu İçin Hesaplanan Endeks Değerleri

\begin{tabular}{lllllll}
\hline & \multicolumn{7}{c}{$\mathbf{8 8 0 2 1 2}$} \\
\hline $\mathbf{2 0 0 2}$ & RCA2 & RCA3 & RXA & RMA & RTA & ES \\
$\mathbf{2 0 0 3}$ & 0,03 & 0,02 & 0,08 & 6,27 & $-6,19$ & $-0,97$ \\
$\mathbf{2 0 0 4}$ & 0,33 & 0,01 & 0,03 & 4,34 & $-4,31$ & $-0,98$ \\
$\mathbf{2 0 0 5}$ & 0,37 & 1,14 & 0,33 & 2,34 & $-2,00$ & $-0,76$ \\
$\mathbf{2 0 0 6}$ & 0,34 & 0,94 & 0,37 & 0,37 & $-0,01$ & $-0,16$ \\
$\mathbf{2 0 0 7}$ & 0,17 & 0,20 & 0,17 & 0,49 & $-0,15$ & $-0,27$ \\
$\mathbf{2 0 0 8}$ & 0,01 & 0,01 & 0,01 & 2,19 & $-1,17$ & $-0,77$ \\
$\mathbf{2 0 0 9}$ & 0,00 & 0,00 & 0,00 & 1,84 & $-1,84$ & $-0,99$ \\
$\mathbf{2 0 1 0}$ & 0,03 & 0,01 & 0,03 & 5,49 & $-5,46$ & $-0,99$ \\
$\mathbf{2 0 1 1}$ & 0,55 & 0,14 & 0,55 & 3,83 & $-3,28$ & $-0,86$ \\
$\mathbf{2 0 1 2}$ & 0,17 & 0,08 & 0,17 & 2,92 & $-2,75$ & $-0,90$ \\
$\mathbf{2 0 1 3}$ & 0,06 & 0,02 & 0,06 & 4,04 & $-3,99$ & $-0,98$ \\
$\mathbf{2 0 1 4}$ & 0,16 & 0,10 & 0,16 & 1,99 & $-1,83$ & $-0,88$ \\
$\mathbf{2 0 1 5}$ & 0,08 & 0,07 & 0,08 & 1,33 & $-1,25$ & $-0,91$ \\
$\mathbf{2 0 1 6}$ & 0,02 & 0,04 & 0,02 & 0,50 & $-0,48$ & $-0,94$ \\
$\mathbf{2 0 1 7}$ & 0,26 & 0,39 & 0,26 & 0,74 & $-0,48$ & $-0,59$ \\
$\mathbf{2 0 1 8}$ & 0,44 & 0,56 & 0,44 & 1,00 & $-0,55$ & $-0,41$ \\
$\mathbf{2 0 1 9}$ & 0,20 & 0,06 & 0,20 & 4,42 & $-4,22$ & $-0,90$ \\
$\mathbf{2 0 2 0}$ & - & 1,05 & - & - & - & $-0,11$ \\
\hline
\end{tabular}

880212 kodlu (Yüksüz ağırlığı 2000 kg'ı ile 15000 kg arasında olan helikopterler) ürün grubu için hesaplanmış olan endeks değerleri tablosu Tablo 7'de verilmiştir. RCA2 endeksinde, incelenen yıllar itibariyle Türkiye'nin karşılaştırmalı üstünlüğünün bulunmadığı görülmüştür. RCA3 endeksinde 2005 ve 2020 yılları dişında bir karşılaştırmalı üstünlüğe rastlanmamıştır.

İnceleme döneminin tamamında, nispi ithalat üstünlüğü endeksinin (RMA), nispi ihracat üstünlügü endeksinden (RXA) yüksek olduğu görülmüştür. Bu nedenle nispi ticaret endeksi (RTA) negatif değerler almıştır. Bu Türkiye'nin 880212 kodlu ürün grubunda rekabet gücünün düşük olduğu şeklinde yorumlanmaktadır. İhracatta uzmanlaşma endeksine bakıldığında (ES) incelenen dönemin tamamında negatif değerler aldığı görülmüştür. Buradan Türkiye'nin ihracatta 880212 kodlu ürün grubunda uzmanlaşmadığı sonucu çıkartılmaktadır.

880220 kodlu (Yüksüz ağırlığı 2000 kg'ı geçmeyen uçaklar ve diğer uçaklar) ürün grubu için hesaplanmış olan endeks değerleri tablosu Tablo 8'de verilmiștir. RCA2 endeksinde, incelenen ylllar itibariyle genellikle Türkiye'nin karşılaştırmalı üstünlüğünün bulunmadığı fakat 2019 yılında yüksek oranda bir karşılaştırmalı üstünlüğün oluştuğu görülmüştür. RCA3 endeksinde 2003, 2012, 2019 ve 2020 yılları dişında bir karşılaştırmalı üstünlüğe rastlanmamıştır. 
Tablo 8. 880220 Kodlu Ürün Grubu İçin Hesaplanan Endeks Değerleri

\begin{tabular}{lllllll}
\hline \multicolumn{7}{c}{$\mathbf{8 8 0 2 2 0}$} \\
\hline $\mathbf{2 0 0 2}$ & RCA2 & RCA3 & RXA & RMA & RTA & ES \\
$\mathbf{2 0 0 3}$ & 0,03 & 0,16 & 0,03 & 0,18 & $-0,15$ & $-0,79$ \\
$\mathbf{2 0 0 4}$ & 0,03 & 1,41 & 0,17 & 0,09 & 0,08 & $-0,02$ \\
$\mathbf{2 0 0 5}$ & 0,01 & 0,00 & 0,03 & 0,10 & $-0,07$ & $-0,67$ \\
$\mathbf{2 0 0 6}$ & 0,21 & 0,56 & 0,21 & 3,03 & $-3,03$ & $-1,00$ \\
$\mathbf{2 0 0 7}$ & 0,04 & 0,24 & 0,04 & 0,53 & $-0,33$ & $-0,49$ \\
$\mathbf{2 0 0 8}$ & 0,01 & 0,02 & 0,01 & 0,37 & $-0,12$ & $-0,73$ \\
$\mathbf{2 0 0 9}$ & 0,06 & 0,02 & 0,06 & 1,02 & $-0,96$ & $-0,98$ \\
$\mathbf{2 0 1 0}$ & 0,07 & 0,00 & 0,07 & 7,91 & $-7,84$ & $-0,99$ \\
$\mathbf{2 0 1 1}$ & 0,03 & 0,00 & 0,03 & 4,67 & $-4,64$ & $-1,00$ \\
$\mathbf{2 0 1 2}$ & 0,51 & 1,05 & 0,51 & 0,29 & 0,22 & $-0,19$ \\
$\mathbf{2 0 1 3}$ & 0,02 & 0,01 & 0,02 & 0,88 & $-0,87$ & $-0,99$ \\
$\mathbf{2 0 1 4}$ & 0,05 & 0,06 & 0,05 & 1,04 & $-0,99$ & $-0,92$ \\
$\mathbf{2 0 1 5}$ & 0,07 & 0,15 & 0,07 & 0,48 & $-0,42$ & $-0,82$ \\
$\mathbf{2 0 1 6}$ & 0,03 & 0,04 & 0,03 & 1,77 & $-1,73$ & $-0,94$ \\
$\mathbf{2 0 1 7}$ & 0,02 & 0,08 & 0,02 & 0,30 & $-0,28$ & $-0,90$ \\
$\mathbf{2 0 1 8}$ & 0,11 & 0,47 & 0,11 & 0,14 & $-0,03$ & $-0,48$ \\
$\mathbf{2 0 1 9}$ & 21,99 & 52,56 & 27,87 & 0,47 & 27,41 & 0,96 \\
$\mathbf{2 0 2 0}$ & - & 23,93 & - & - & - & 0,90 \\
\hline
\end{tabular}

İnceleme dönemde genel olarak, nispi ithalat üstünlüğü endeksinin (RMA), nispi ihracat üstünlüğü endeksinden (RXA) yüksek olduğu görülmüştür. Bu nedenle nispi ticaret endeksi (RTA) negatif değerler almıştır. Fakat 2019 yılında RTA endeksinin 27,87 gibi yüksek bir değere ulaştığı görülmüştür. Buradan Türkiye'nin 880220 kodlu ürün grubunda rekabet gücünün düşük olduğu fakat özellikle 2019 yılında yüksek bir rekabet gücünün elde edildiği şeklinde yorumlanmaktadır. İhracatta uzmanlaşma endeksine bakıldığında (ES) incelenen dönemlerde genellikle negatif değerler aldığı 2019 ve 2020 yıllarında ise endeksin en yüksek değeri olan +1'e çok yakın seyrettiği görülmüştür. Buradan Türkiye'nin ihracatta 880220 kodlu ürün grubunda özellikle son yllarda bir uzmanlaşmasının olduğu sonucu çıkartılmaktadır.

880230 kodlu (Yüksüz ağırlığı 2000 kg'ı ile 15000 kg arasında olan uçaklar ve diğer uçaklar) ürün grubu için hesaplanmış olan endeks değerleri Tablo 9'da verilmiştir. RCA2 endeksinde, incelenen yıllar itibariyle Türkiye'nin karşılaștırmalı üstünlüğünün bulunmadığı görülmüştür. RCA3 endeksinde, incelenen yıllar itibariyle 2003, 2015, 2017 ve 2019 yılları dışında Türkiye'nin karşılaștırmalı üstünlüğünün bulunmadığı görülmüştür.

Tablo 9. 880230 Kodlu Ürün Grubu İçin Hesaplanan Endeks Değerleri

\begin{tabular}{lllllll}
\hline & \multicolumn{7}{c}{$\mathbf{8 8 0 2 3 0}$} & & \\
\hline $\mathbf{2 0 0 2}$ & RCA2 & RCA3 & RXA & RMA & RTA & ES \\
$\mathbf{2 0 0 3}$ & 0,25 & 0,77 & 0,25 & 0,40 & $-0,15$ & $-0,30$ \\
$\mathbf{2 0 0 4}$ & 0,08 & 5,70 & 0,34 & 0,00 & 0,34 & 0,99 \\
$\mathbf{2 0 0 5}$ & 0,05 & 0,17 & 0,08 & 0,47 & $-0,39$ & $-0,80$ \\
$\mathbf{2 0 0 6}$ & 0,05 & 0,08 & 0,05 & 0,25 & $-0,19$ & $-0,77$ \\
$\mathbf{2 0 0 7}$ & 0,44 & 0,60 & 0,44 & 0,58 & $-0,54$ & $-0,91$ \\
$\mathbf{2 0 0 8}$ & 0,06 & 0,11 & 0,06 & 0,89 & $-0,45$ & $-0,45$ \\
$\mathbf{2 0 0 9}$ & 0,21 & 0,10 & 0,21 & 1,50 & $-0,34$ & $-0,87$ \\
$\mathbf{2 0 1 0}$ & 0,14 & 0,08 & 0,14 & 1,34 & $-1,21$ & $-0,87$ \\
$\mathbf{2 0 1 1}$ & 0,07 & 0,12 & 0,07 & 0,51 & $-0,44$ & $-0,90$ \\
$\mathbf{2 0 1 2}$ & 0,40 & 0,31 & 0,40 & 1,23 & $-0,83$ & $-0,66$ \\
$\mathbf{2 0 1 3}$ & 0,04 & 0,02 & 0,04 & 1,95 & $-1,92$ & $-0,97$ \\
$\mathbf{2 0 1 4}$ & 0,50 & 0,36 & 0,50 & 1,84 & $-1,33$ & $-0,62$ \\
$\mathbf{2 0 1 5}$ & 0,71 & 1,36 & 0,72 & 0,62 & 0,10 & $-0,03$ \\
$\mathbf{2 0 1 6}$ & 0,47 & 0,34 & 0,47 & 1,79 & $-1,32$ & $-0,61$ \\
$\mathbf{2 0 1 7}$ & 0,52 & 1,11 & 0,52 & 0,45 & 0,07 & $-0,15$ \\
$\mathbf{2 0 1 8}$ & 0,11 & 0,45 & 0,11 & 0,21 & $-0,10$ & $-0,50$ \\
$\mathbf{2 0 1 9}$ & 0,21 & 2,20 & 0,21 & 0,07 & 0,14 & 0,31 \\
$\mathbf{2 0 2 0}$ & - & 0,05 & - & - & - & $-0,92$ \\
\hline
\end{tabular}

İnceleme dönemde genel olarak, nispi ithalat üstünlüğü endeksinin (RMA), nispi ihracat üstünlüğü endeksinden (RXA) yüksek olduğu görülmüştür. $\mathrm{Bu}$ nedenle nispi ticaret endeksi (RTA) 2003, 2015, 2017 ve 2019 yılları dışında negatif değerler almıştır. İhracatta uzmanlaşma endeksine bakıldığında (ES) incelenen dönemde 2003 ve 2019 yılları dişında negatif değerler aldığı görülmüștür. Buradan Türkiye'nin ihracatta 880230 kodlu ürün grubunda özellikle son ylllarda bir uzmanlaşmanın olduğu sonucuna varılabilir.

Çalışmada yer alan tüm ürün gruplarının toplamları için hesaplanmış olan endeks değerleri Tablo 10'da yer almaktadır. RCA2 endeksinde, incelenen yıllar itibariyle genellikle Türkiye'nin karşılaştırmalı üstünlüğünün bulunmadığı fakat 2019 yılında karşılaştırmalı üstünlüğün oluştuğu görülmüștür. RCA3 endeksinde 2019 ve 2020 yılları dışında bir karşılaştırmalı üstünlüğe rastlanmamıştır.

İnceleme dönemde genel olarak, nispi ithalat üstünlüğü endeksinin (RMA), nispi ihracat üstünlüğü endeksinden (RXA) yüksek olduğu görülmüştür. $\mathrm{Bu}$ nedenle nispi ticaret endeksi (RTA) negatif değerler almıștır. Fakat 2019 yılında RTA endeksinin 0,55'e ulaştığl görülmüştür. Buradan Türkiye'nin İHA'larda rekabet gücünün düşük olduğu fakat 2019 yılında bir rekabet gücünün elde edildiği sonucu çıkarılmaktadır. İhracatta uzmanlaşma endeksine bakıldığında (ES) incelenen dönemlerde genellikle negatif değerler aldığı 2019 ve 2020 ylllarında ise endeksin pozitif değerler aldığı görülmüştür. Buradan Türkiye'nin ihracatta İHA'larda özellikle son yıllarda bir uzmanlaşmasının olduğu sonucuna varılmıștır.

Tablo 10. Çalışmada Yer Alan Ürün Gruplarının Toplamı İçin Hesaplanan Endeks Değerleri

\begin{tabular}{lllllll}
\hline \multicolumn{7}{c}{ TOPLAM } \\
\hline $\mathbf{2 0 0 2}$ & RCA2 & RCA3 & RXA & RMA & RTA & ES \\
$\mathbf{2 0 0 3}$ & 0,22 & 0,28 & 0,22 & 1,01 & $-0,79$ & $-0,67$ \\
$\mathbf{2 0 0 4}$ & 0,11 & 0,93 & 0,27 & 0,33 & $-0,06$ & $-0,22$ \\
$\mathbf{2 0 0 5}$ & 0,11 & 0,18 & 0,11 & 0,61 & $-0,50$ & $-0,79$ \\
$\mathbf{2 0 0 6}$ & 0,11 & 0,20 & 0,11 & 0,40 & $-0,28$ & $-0,70$ \\
$\mathbf{2 0 0 7}$ & 0,33 & 0,50 & 0,11 & 0,58 & $-0,47$ & $-0,78$ \\
$\mathbf{2 0 0 8}$ & 0,04 & 0,06 & 0,04 & 0,85 & $-0,51$ & $-0,52$ \\
$\mathbf{2 0 0 9}$ & 0,13 & 0,06 & 0,13 & 1,64 & $-0,52$ & $-0,93$ \\
$\mathbf{2 0 1 0}$ & 0,09 & 0,03 & 0,09 & 2,64 & $-2,56$ & $-0,92$ \\
$\mathbf{2 0 1 1}$ & 0,20 & 0,11 & 0,20 & 1,63 & $-1,43$ & $-0,86$ \\
$\mathbf{2 0 1 2}$ & 0,31 & 0,21 & 0,31 & 1,46 & $-1,16$ & $-0,76$ \\
$\mathbf{2 0 1 3}$ & 0,04 & 0,02 & 0,04 & 2,38 & $-2,34$ & $-0,98$ \\
$\mathbf{2 0 1 4}$ & 0,37 & 0,25 & 0,37 & 1,86 & $-1,49$ & $-0,72$ \\
$\mathbf{2 0 1 5}$ & 0,45 & 0,65 & 0,45 & 0,76 & $-0,30$ & $-0,38$ \\
$\mathbf{2 0 1 6}$ & 0,28 & 0,27 & 0,28 & 1,26 & $-0,98$ & $-0,68$ \\
$\mathbf{2 0 1 7}$ & 0,41 & 0,77 & 0,41 & 0,52 & $-0,11$ & $-0,32$ \\
$\mathbf{2 0 1 8}$ & 0,21 & 0,49 & 0,21 & 0,38 & $-0,17$ & $-0,46$ \\
$\mathbf{2 0 1 9}$ & 1,50 & 1,34 & 1,53 & 0,98 & 0,55 & 0,07 \\
$\mathbf{2 0 2 0}$ & - & 3,10 & - & - & - & 0,41 \\
\hline
\end{tabular}

\section{SONUÇ VE TARTIŞMA}

Özellikle son yıllarda İHA'ların hem sivil hem de askeri alanlarda kullanımı yaygınlaşmıștır. İHA'lar kullanım amacına göre donatılabilmeleri ve tasarlanabilmeleri ile diğer birçok hava aracının önüne geçmektedirler. İHA'ların kullanım alanları artıkça, bu araçlara olan talepte artmıştır. Günümüzde İHA ticareti, diş ticarette önemli bir kalem haline gelmeye başlamaktadır. İHA üretimi ileri teknoloji gerektiren bir çabadır. İHA üretimi yapan ülkeler gerekli teknolojileri geliştirmekte ve yayılma etkisi ile bu diğer sektörlerde de 
teknolojinin gelişmesini beraberinde getiren bir süreci ortaya çıkartmaktadır.

İHA pazarının daha da gelişeceği tahmin edildiğinde, bu sektöre erken dönemlerde dahil olmanın avantajlı olacağı sonucuna varılabilir. Türkiye bu sektöre erken dahil olan ülkelerden birisidir. Bu durum Türkiye'nin teknoloji üretmesinin yanında, İHA ticaretinden yüksek paylar almasına dolayısıyla dış ticaret açıklarının azalmasına da fayda sağlayacaktır. Türkiye özellikle askeri İHA ve SİHA teknolojilerine ağırlı vermiş gözükmektedir. Bu durum Türkiye'nin savunma sanayinde dışa bağımlılığını azaltıcı etki yapmaktadır. Ayrıca SİHA teknolojisi için erken bir dönemde üstünlük elde edilmesi, Türkiye'nin bölgesinde askeri ve politik gücünü de artırmaktadır. Örneğin; 2020 yılında yaşanan Karabağ Savaşında Türk İHA ve SİHA'ları Azerbaycan saflarında yer almışlar ve başarılı operasyonlar gerçekleştirmişlerdir. Bazı askeri uzmanlara göre Azerbaycan'ın Karabağ'daki başarısının en önemli aktörlerinden birisi Türk SİHA'ları olmuștur.

Çalışmada özellikle son yıllarda Türkiye'nin İHA alanında bir atılım yaptığı ve bunun ihracat rakamlarına yansıdığı görülmüștür. Analiz kapsamında yer alan ürün grupları içerisinde özellikle 880220 kodlu ürün grubunda ihracat rekabet gücünün arttığl, karşılaştırmalı üstünlüğün oluştuğu ve ihracatta uzmanlaşmanın ortaya çıtığı görülmüştür. $\mathrm{Bu}$ ürün grubunda görülen yükselişlerin nedeninin Türkiye'nin askeri İHA ve SİHA'larda özellikle son dönemlerde yapmış olduğu atılımdan kaynaklandığı düşünülmektedir. Ayrıca Türkiye'nin ürettiği askeri İHA ve SİHA'ların 2000 kg'ın altında olduğu düşünüldüğünde bu ürünlerin 880220 (Yüksüz ağırlığı 2000 kg'ı geçmeyen uçaklar ve diğer uçaklar) kodlu ürün grubuna dahil olduğu söylenebilmektedir.

Türkiye'nin İHA teknolojisini geliştirmeye erken sayılabilecek bir dönemde başlamış olması son derece önemlidir. Türkiye bu yolla; teknoloji üreten ve geliștiren bir ülke konumuna gelme, savunma sanayinde dișa bağımlılığını azaltma, üretilen teknoloji sayesinde diğer sektörlerde de teknolojinin ilerlemesini sağlama ve ihracat yoluyla dıș ticaret açıklarını azaltma gibi faydalar elde edecektir. Türkiye'nin İHA geliștirmeye devam etmesi, geliştirmelerin kolaylaşması için bazı teşviklerin sağlanması faydalı olacaktır.

\section{KAYNAKÇA}

Akkamış M \& Çalışkan S (2020). İnsansız Hava Araçları ve Tarımsal Uygulamalarda Kullanımı. Türkiye İnsansız Hava Araçları Dergisi, 2(1), 08-16.

Aksan S (2020). Türkiye'nin gökyüzündeki başarı imzası: Yerli İHA ve SİHA'lar. TRT Haber Web Sitesi:https://www.trthaber.com/haber/gundem/t urkiyenin-gokyuzundeki-basari-imzasi-yerli-ihave-sihalar-464449.html/, Giriş: 03.02.2021

Arjomandi M (2007). Classification of Unmanned Aerial Vehicles. The University of AdelaideWebSitesi:https://www.academia.edu/20 55673/Classification_of_Unmanned_Aerial_Vehicles /, Giriş: 05.02.2021
Bakır G (2019). İnsansız Hava Araçlarının Savunma Sanayi Harcamasında Yeri ve Önemi. Avrasya Sosyal ve Ekonomi Araştırmaları Dergisi, 6(2), 127-134.

Business Insider Intelligence (2020). Commercial Unmanned Aerial Vehicle (UAV) Market Analysis Industry trends, forecasts and companies. Business Insider Intelligence Web Sitesi: https://www.businessinsider.com/commercialuav-market-analysis /, Giriș: 10.02.2021

Demir K A, Cicibaş H \& Arıca N (2015). Unmanned Aerial Vehicle Domain: Areas of Research Kadir. Defence Science Journal, 65(4), 319-329.

Dikmen M (2015). İnsansız Hava Aracı (İHA) Sistemlerinin Hava Hukuku Bakımından İncelenmesi. Savunma Bilimleri Dergisi, 14(1), 145176.

Düz S (2020). The Ascension of Turkey as a Drone Power: History, Strategy, and Geopolitical Implications. Ankara: SETA.

Erdağ R (2020). Savaş ve Çatışmanın Değișen Yapısı: Silahların İnsansızlaştırılması. Güvenlik Çalışmaları Dergisi, 22(1), 3-22.

European Commision (2017) Project group dealing with classification of products in the HS/CN nomenclatures - Mechanical/Miscellaneous, European Commision Web Sitesi, https://ec.europa.eu/transparency/regexpert/inde x.cfm?do=groupDetail.groupDetail\&groupID=3159 / Accessed 29.01.2021.

Gettinger D (2020). The Drone Databook. The Drone DatabookWebSitesi,https://dronecenter.bard.edu/ projects/drone-proliferation/databook/, Accessed 12.02.2021.

Kahveci M \& Can N (2017). İnsansız Hava Araçları: Tarihçesi, Tanımı, Dünyada ve Türkiye'deki Yasal Durumu. Selçuk Üniversitesi Mühendislik Bilim ve Teknik Dergisi, 5(4), 511-535.

Kahvecioğlu S \& Oktal H (2014). Turkish UAV capabilities as a new competitor in the market. International Journal of Intelligent Unmanned Systems, 2(3), 183191.

Kurt Ş \& Ün O (2015). İnsansız Hava Araçları (İHA) Üzerine Hava Hukuku Açısından Bir Değerlendirme. Erciyes Üniversitesi Hukuk Fakültesi Dergisi, 10(2), 195-213.

Nişancı M H, Teşneli A Y \& Teşneli N B (2018). Yıldırım Darbelerinin Silahlı İnsansız Hava Araçları (SİHA) Üzerindeki Dolaylı Etkilerinin Analizi. Mühendislik Bilimleri ve Tasarım Dergisi, 6(3), 390-395. 
Seymen D A (2009). Türkiye'nin Dış Ticaret Yapısı ve Rekabet Gücü. Dokuz Eylül Üniversitesi Yayınları,1, ISBN 9789754412628.

Sivil Havacılık Genel Müdürlüğü (2020). 2019 Faaliyet Raporu. Ankara: Sivil Havacılık Genel Müdürlüğü, /, Giriș: 12.02.2021.

Şen 0 \& Akarslan H (2020). Terrorist Use of Unmanned Aerial Vehicles: Turkey's Example. Defence Against Terrorism Review, 13, 49-84.

Şimşek N \& Sadat S A (2009). ECO Pazarında Türkiye: 1997-2005 Dönemi Rekabet Gücü Analizi. Sosyoekonomi, 2, 135-157.

Türk A (2020). An Investigation For Maturity Level And Roadmap Of Unmanned Aerial Vehicle Technologies In Turkey, Yüksek Lisans Tezi, Orta Doğu Teknik Üniversitesi, Sosyal Bilimler Enstitüsü, Ankara, 35s.

Türkseven S, Kızmaz M Z, Tekin A B, Urkan E \& Serim A T (2016). Tarımda Dijital Dönüşüm; İnsansız Hava Araçları Kullanımı. Tarım Makinaları Bilimi Dergisi, 12 (4), 267-271.

Urcosta R B (2020). The Revolution in Drone Warfare The Lessons from the Idlib De-Escalation Zone. European, Middle Eastern \& African Affairs, 50-65.
Vollrath T L (1991). A theoretical evaluation of alternative trade intensity measures of revealed comparative advantage. Weltwirtschaftliches Archiv, 127, 265-280.

Yanarocak H E (2020, Ağustos 13). Turkey's Giant Leap: Unmanned Aerial Vehicles. The Moshe Dayan CenterWebSitesi:https://dayan.org/content/turke ys-giant-leap-unmanned-aerial-vehicles/,Giriș: 05.02.2021

Yardımcı G (2019). İnsansız Hava Araçlarına Türk Mevzuatından Bir Bakıș. Journal of Aviation, 3 (1), 61-80.

Yeșilay R B \& Macit A (2019). Economic Outlook of Unmanned Aerial Vehicles in Turkey and The World: "Drone Economics". 3rd International Conference on Economic Research (Econ Alanya), Antalya, Türkiye, 209-214.

Yılmaz H M, Mutluoğlu Ö, Ulvi A, Yaman A \& Bilgilioğlu S S. (2018). İnsansız Hava Aracı ile Ortofoto Üretimi ve Aksaray Üniversitesi Kampüsü Örneği. Geomatik Dergisi, 3(2), 129-136.

(C) Author(s) 2021.

This work is distributed under https://creativecommons.org/licenses/by-sa/4.0/ 